\title{
Compliance of surgeons and nurses in scrubbing time before surgery
}

Taha Allafi Rababa'h, Zeid Al-Adwan, ${ }^{2}$ Ghazi Dahayat, ${ }^{3}$ Hayel Gharaibeh ${ }^{4}$ and Ibrahim Al-Amr ${ }^{5}$

$$
\begin{aligned}
& \text { التزام المجراحين والمهر ضات بمدة تنظيفس الأيلي بالفرشاة قبل العمليات البلراحيّة }
\end{aligned}
$$

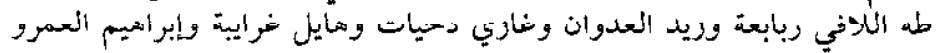

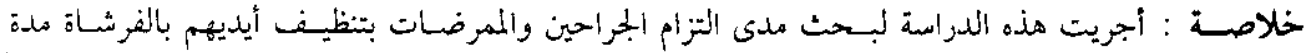

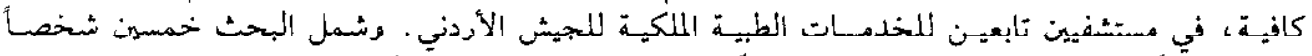

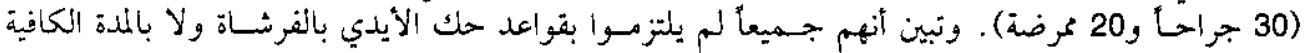

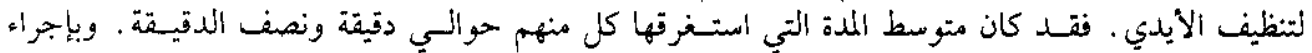

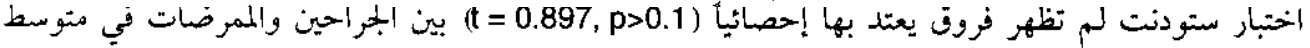

$$
\begin{aligned}
& \text { مدة تنظيف الأيدي. }
\end{aligned}
$$

ABSTRACT This study was carried out to investigate the compliance of surgeons and nurses in performing sufficiently long scrubbing in two hospitals of the Royal Medical Services of the Jordanian Army. Fifty subjects ( 30 surgeons and 20 nurses) were examined. It was found that none of the subjects complied with the rules concerning scrubbing technique and scrubbing time. The average time for each subject was about 1.5 minutes. Student $t$-test showed that there was no significant difference $(t=0.897 ; P>0.1)$ in the mean scrubbing time between surgeons and nurses.

Respect du temps de lavage chirurgical des mains par les chirurgiens et les ìnfirmières avant une intervention chirurgicale

RESUME Cette étude a été réalisée pour examiner si les chirurgiens et les infirmières effectuent un lavage chirurgical des mains sutfisamment long dans deux hôpitaux des Services médicaux royaux de l'Armée jordanienne. Cinquante personnes ( 30 chirurgiens et 20 infirmières) ont été contrôlées. Il s'est avéré qu'aucune d'entre elles n'avait observé les règles concernant la technique et la durée du lavage chirurgical des mains. Le temps moyen pour chaque personne était d'environ une minute et demie. Le test $t$ (test de Student) a montré qu'il n'y avait aucune différence significative $(t=0,897 ; P>0,1)$ entre les chirurgiens et les infirmières pour le temps moyen de lavage chirurgical des mains.

'Senior Specialist in Dental Public Health and Periodontology and part-time lecturer at the University of Science and Technology, Irbid, Jordan.

${ }^{2}$ Consultant in Dermatology and Director of Princess Haya Hospital; ${ }^{3}$ Anaesthesiologist; ${ }^{5}$ Head of Department of ENT, Princess Haya Hospital, Aqaba, Jordan.

${ }^{4}$ Anaesthesiologist. King Hussein Medical Centre, Jordan.

Received: 17/06/96; accepted: 21/10/96

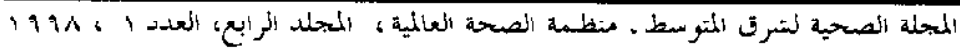




\section{Introduction}

Infection means the depositing of organisms in tissues and their growth resulting in a host reaction. Cross-infection can be defincd as the transmission of infectious agents among patients and staff within a clinical environment [l]. Infection control in the clinic should be a primary concern of every medical care worker. Many measures are now available for medical and dental teanis tu break the chain of cruss-infection, such as [2]:

- careful patient evaluation

- use of disposables

- laboratory asepsis

- sterilization and disinfection

- personal protection.

There is a consensus in the medical profession that effectlve scrubbing is mandatory to protect the patient and the medical team from infection before and after performing surgery. Handwashing or disinfection prevents cross-infection, although hospital cross-infection is variable. Despite this, there is no agreed precise and definite scrubbing technique; however, there is a general agreement that the application time of 3 minutes can be used for the evaluation of surgical scrub disinfectants for international guidelines [3].

The aims of this study were to examine the degree of compliance of surgeons and nurses in scrubbing before starting surgery, and also to encourage a policy of quality control.

\section{Subjects and methods}

The study was carried out simultaneously in two military hospitals of the Royal Medical Services of the Jordanian Army. Fifty medical personnel were examined; 30 surgeons and 20 nurses. Two anaesthesiologists (one in each hospital) recorded the scrubbing time of each surgeon and nurse without their knowledge. Each surgeon and nurse was given a number and no names were registered. Recordings were made on three occasions and the mean value of scrubbing time for each starl member was estimated.

\section{Results}

Table 1 shows the scrubbing times on three occasions of the surgeons (mean $92.6 \mathrm{sec}$ onds, $s=13.4$ seconds). No surgeon achieved the minimum required time for scrubbing which is 3 minutes. They all had a mean scrubbing time of about $1.5 \mathrm{~min}$ utes. Table 2 sloows the scrubbing tines of the nurses. The mean scrubbing time was 89.1 seconds, which shows also that none achieved the minumum required time for scrubbing. Student $t$-test showed that there was no significant difference in the mean scrubbing line between the surgeons and nurses $(t=0.897, P>0.1)$.

\section{Discussion}

The personal hygiene of a medical team who are directly or indirectly dealing with patients should be meticulous. Generally, touching anything not required for the particular procedure should be avoided. Surgeons, dentists and nurses should avoid touching their eyes, nose, mouth and hair. In an epidemiological study by Rossello et al. [4], cross-infection via the hands of personnel caring for patients was the most probable mode of spread of organisms. 
Table 1 Surgeons and their scrubbing times

\begin{tabular}{llccc}
\hline Surgeon & \multicolumn{3}{c}{ Scrubbing time (seconds) } \\
\cline { 2 - 4 } & First & Second & Third & Mean \\
& scrub & scrub & scrub & \\
&
\end{tabular}

\begin{tabular}{|c|c|c|c|c|}
\hline 1 & 70 & 75 & 75 & 73.3 \\
\hline 2 & 100 & 105 & 110 & 101.6 \\
\hline 3 & 90 & 100 & 105 & 98.3 \\
\hline 4 & 80 & 80 & 85 & 81.6 \\
\hline 5 & 70 & 75 & 70 & 71.6 \\
\hline 6 & 80 & 80 & 90 & 83.3 \\
\hline 7 & 100 & 95 & 110 & 101.6 \\
\hline 8 & 100 & 95 & 110 & 101.6 \\
\hline 9 & 80 & 85 & 80 & 81.6 \\
\hline 10 & 75 & 70 & 80 & 75.0 \\
\hline 11 & 90 & 95 & 100 & 95.0 \\
\hline 12 & 80 & 80 & 85 & 81.6 \\
\hline 13 & 110 & 100 & 105 & 105.0 \\
\hline 14 & 95 & 95 & 100 & 96.6 \\
\hline 15 & 100 & 110 & 90 & 100.0 \\
\hline 16 & 110 & 06 & 120 & 108.3 \\
\hline 17 & 100 & 1 to & 95 & 101.6 \\
\hline 18 & 90 & 85 & 95 & 90.0 \\
\hline 19 & 90 & 100 & 95 & 95.0 \\
\hline 20 & 80 & 90 & 85 & 85.0 \\
\hline 21 & 90 & 90 & 95 & 91.6 \\
\hline 22 & 80 & 90 & 85 & 85.0 \\
\hline 23 & 110 & 105 & 80 & 98.3 \\
\hline 24 & 95 & 90 & 100 & 95.0 \\
\hline 25 & 115 & 120 & 115 & 116.6 \\
\hline 26 & 70 & 75 & 70 & 71.6 \\
\hline 27 & 110 & 125 & 115 & 116.6 \\
\hline 28 & 120 & 105 & 100 & 108.3 \\
\hline 20 & 110 & 100 & 100 & 103.3 \\
\hline 30 & 65 & 70 & 65 & 66.6 \\
\hline Total & 2755 & 2790 & 2810 & 2780.5 \\
\hline \multirow[t]{2}{*}{ Total mean } & 91.8 & 93.0 & 93.6 & 92.6 \\
\hline & & & & $s=13.4$ \\
\hline
\end{tabular}

$s=$ standard devlation
Table 2 Nurses and their scrubbing times

\begin{tabular}{|c|c|c|c|c|}
\hline \multirow[b]{2}{*}{ Nurse } & \multicolumn{4}{|c|}{ Serubbing time (seconds) } \\
\hline & $\begin{array}{l}\text { First } \\
\text { scrub }\end{array}$ & $\begin{array}{l}\text { Second } \\
\text { scrub }\end{array}$ & $\begin{array}{l}\text { Third } \\
\text { scrub }\end{array}$ & Mean \\
\hline 1 & 90 & 90 & 65 & 81.6 \\
\hline 2 & 105 & 100 & 100 & 101.6 \\
\hline 3 & 80 & 80 & 100 & 86.6 \\
\hline 4 & 60 & 75 & 65 & 66.6 \\
\hline 5 & 80 & 65 & 70 & 71.6 \\
\hline 6 & 80 & 65 & 70 & 71.6 \\
\hline 7 & 85 & 75 & 70 & 76.6 \\
\hline 8 & 80 & 65 & 60 & 68.3 \\
\hline 9 & 90 & 95 & 95 & 93.3 \\
\hline 10 & 80 & 85 & 80 & 81.6 \\
\hline 11 & 110 & 110 & 105 & 708.3 \\
\hline 12 & 100 & 110 & 105 & 105.0 \\
\hline 13 & 80 & 85 & 85 & 83.3 \\
\hline 14 & 90 & 100 & 100 & 96.6 \\
\hline 15 & 100 & 95 & 110 & 101.6 \\
\hline 10 & 90 & 95 & 95 & 90.3 \\
\hline 17 & 110 & 115 & 100 & 108.3 \\
\hline 18 & 110 & 100 & 95 & 101.6 \\
\hline 19 & 90 & 100 & 110 & 100.0 \\
\hline 20 & 80 & 85 & 90 & 85.0 \\
\hline Total & 1790 & 1790 & 1770 & 1782.4 \\
\hline Total mean & 89.5 & 89.5 & 88.5 & 89.1 \\
\hline & & & & $s=13.7$ \\
\hline
\end{tabular}

$\mathbf{s}=$ standard deviation

Handwashing techniques should be developed so that all areas of the hands are perfectly washed. A recommended antimicrobial handwash should be used prior to wearing gloves. Gloves should be removed when patient contact is over, hands should be rewashed, rinsed thoroughly in cool water and a hand cream applied to prevent excessive drying of the skin. I lands should be 
washed with an antiseptic solution before leaving the clinic. It is essential that new gloves be worn for surgical cases or any other treatment which results in blood or saliva contamination. It is believed that up to $80 \%$ of gloves may perforate during dental surgery, and one half of them become permeable to bacteria after several hours of use. Hence, it is recommended that gloves should be changed hourly for long procedures on the same patient [2].

In our study, most of the surgeons were graduates from different medical schools and different countries; consequently there was no common technique for handwashing.

A large number of different disinfectant preparations are available, but the absence of agreed tests makes it difficult for manufacturers to produce products which are internationally acceptable [5]. In many disinfectant tests, a five log reduction in selected organisms over a period of 5 minutes is required [3]. Rossello et al. [4] recommended that antiseptics for surgical scrubbing should be accepted on the basis of a 3minute application time, provided they achieve a similar or greater antimicrobial potency when compared with the standard of $60 \%(V / V) n$-propyl alcohol with a 5 minute exposure time. The range of exposure time in several European countries varies from 2 to 5 minutes [ 6 ]. The degree of microbial reduction obtained by hand disinfection which is necessary for effective prophylaxis of surgical wound infections is unknown, and may remain so for methodological and ethical reasons [5]. Litlle new work has beeri done un tests for surgical hand disinfection, but more interest has been shown in hygienic hand disinfection, e.g. the killing (or removal) of transients.
Heeg et al. [7] showed that handwashing prior to surgical hand disinfection, whether a brush was used or not, did not affect the efficiency of the subsequent disinfection procedure. However, there is still some disagreement as to whether physical removal of organisms should be considered part of the disinfection process. In the United Kingdom, United States of America and Scandinavia, it is generally accepted that both mechanisms are a part of disinfection [2]. Many factors may influence the efficacy of a disinfection procedure, such as the kind of antiseptic used, the experience of the subject in performing hand disinfection, time exposure and the method of counting microbial cells.

In dentistry in the United Kingdom, compliance with cross-infection control measures is poor, even when clinicians are provided with appropriate facilities. Only $50 \%$ of staff or students wore protective eyewear and only about one-third wore a face mask [8]. In a recent study, in only $56 \%$ of health care worker-patient contacts were protective gloves changed between patients. Face masks and eyewear were only worn in $38 \%$ and $29 \%$ of such contacts respectively [9].

Our study would have been more valuable if we had estimated the incidence of post-operative wound infection; unfortunately, this could not be done for several reasons. In addition, it would be unrealistic to ascribe post-operative wound infection to incomplete scrubbing time only. However, we have been assured that the infection rate in the two hospitals is within international standards.

We believe that a common, precise and effective handwashing technique (surgical and hygienic) and an effective antiseptic should be adopted for all health care workers in the Royal Medical Services. 


\section{References}

1. Samaranayake LP. Infection control in dentistry. Postgraduate dentist, 1995, (3):88-91.

2. Samaranayake LP. Infection control in dentistry. Postgraduate dentist, 1995 , 5(4):108-11.

3. Hingst $V$ et al. Evaluation of the efficacy of surgical hand disinfection following a reduced application time of 3 instead of 5 minutes. Journal of hospital infection, 1992, 20:79-86.

4. Rossello $\mathrm{J}$ et al. Investigation of an outbreak of nosocomial infection due to a multiple drug-resistant strain of Pseudomonas aeruginosa. Journal of hospital infection, 1992, 20:87-96.

5. Ayliffe GA. Standardization of disinfectant testing. Journal of hospifal infection, 1989, 13:211-6.
6. Reybrouch G. Handwashing and hand disinfection. Journal of hospital infection, 1986, 8:5-23.

7. Heeg P, Olmar R, Schwenzer N. Verbessern handwaschen und verwendung der handburste das ergebnis der chir-urgischen handedesinfektionen. [Hand-washing and nail-brushing: improvement of the results of surgical hand disinfection]. Hyg. Med. $1988,13: 270-2$.

8. Scully C, Porter SR, Epstein J. Compliance with infection control procedures in a dental hospital clinic. British dental journal, 1992, 173:20-3.

9. Porter SR et al. Cross-infection compliance of UK dental staff and students. Oral diseases, 1995, 4:198-200.

Slogan de la Journée mondiale de la Santé

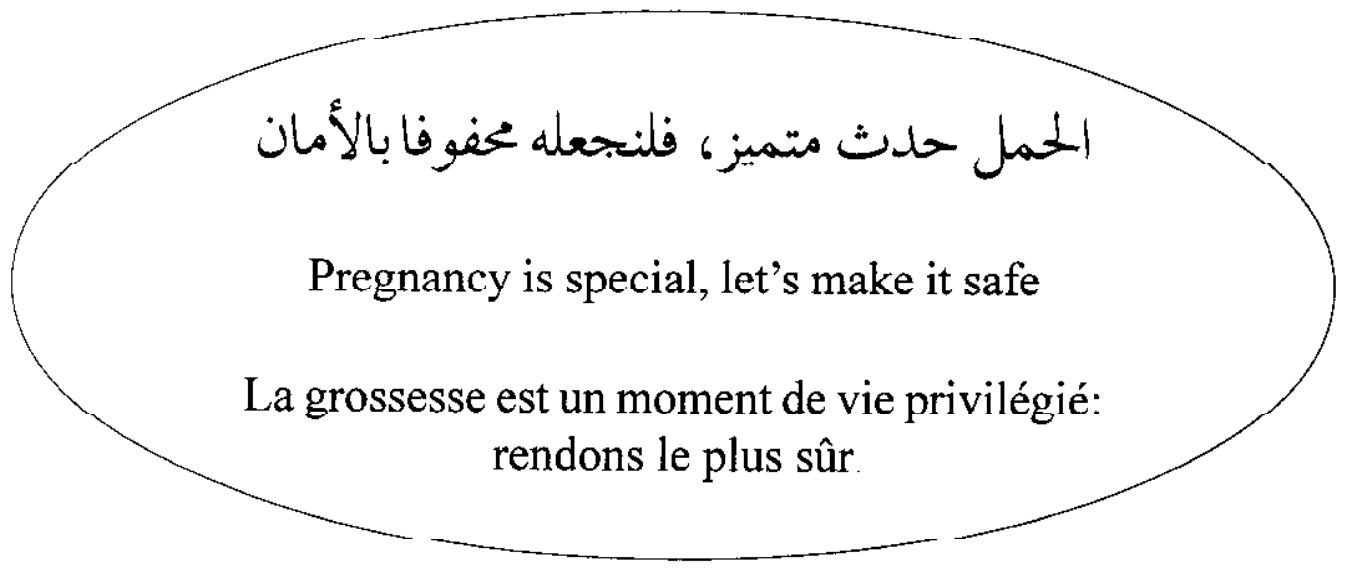

